\title{
Proper Utilization of Waste Water for Farming Purpose in Agriculture with Effective Software Support
}

\author{
Mr.Rajapraveen.k.n ${ }^{1,}$ Dr. N. K. Prasanna kumari ${ }^{2}$ \\ ${ }^{1}$ (M.tech/Department of Computer Science and Engineering Sam Higginbottom Institute of Agriculture, \\ Technology \&Sciences- Deemed University. India) \\ ${ }^{2}$ (NIMH Government of India, Nagpur)
}

\begin{abstract}
Due to the lack of proper knowledge on the quality of water, Indian farmers are facing huge problems these days as the industrial waste water enters into the rivers and are used for irrigation purpose by the farmers.

There is scarcity of water as the water levels are decreasing day by day. As the population continues to increase, the shortage of water becomes eminent. Water quality is also an issue, since runoff from fields makes river water more saline because they carry soluble mineral salts as well as excess nutrients from fertilizer such as nitrogen, phosphorus and potassium. As a result the water may be too salty to use for irrigation further downstream, since most crops cannot cope with salty water.

By making the farmers aware of quality usage of water we can help them to tackle the major problems related to water.
\end{abstract}

Keywords: Reduction of farmer's problem, water problem in agriculture, reclaimed water in agriculture

\section{Introduction}

Reclaimed water is another viable option to reduce potable water demand, as well as to reduce or eliminate wastewater discharge to aquatic environment.

Reclaimed water can be advantageous to crops due to the nutrients that it contains. Nitrogen, phosphorus, and potassium are the main macronutrients found in reclaimed water and are considered to be beneficial to irrigation at certain levels. If the level of nutrients in reclaimed water is higher than the desired level, reclaimed water quality can be altered through nutrient removal, or by blending it with water from other sources. The feasibility of water reuse for agricultural irrigation using existing facilities will depend on the location of the facilities in relation to the crops, the type of crop, the quality and quantity of the reclaimed water, and the cost of providing the reclaimed water. The existing facilities may have to be upgraded in order to use the reclaimed water for irrigation

\section{Reclaimed Water}

Reclaimed water, also known as recycled water, is recovered from domestic, municipal, and industrial wastewater treatment plants that have been treated to standards that allow safe reuse. Properly reclaimed water is typically safe for most uses except for human consumption.

Wastewater is not reclaimed water. Wastewater is untreated liquid industrial waste and/or domestic sewage from residential dwellings, commercial buildings, and industrial facilities. Gray water, or untreated wastewater from bathing or washing, is one form of wastewater. Wastewater may be land applied, but this is considered to be land treatment rather than water reuse. Reclaimed water or recycled water, is treated to remove solids and certain impurities, and used to recharge groundwater aquifers. The purpose of these processes is sustainability and water conservation, rather than discharging the treated water to surface waters such as rivers and oceans.

Wastewater is highly engineered for safety and reliability so that the quality of reclaimed water is more predictable than many existing surface and groundwater sources. Reclaimed water is considered safe when appropriately used. Reclaimed water planned for use in recharging aquifers or augmenting surface water receives adequate and reliable treatment before mixing with naturally occurring water and undergoing natural restoration processes. Some of this water eventually becomes part of drinking water supplies.

\section{Reclaimed Water Process}

1. Screens and other processes remove sand and debris

2. Sedimentation removes large solids

3. Microorganisms break down organic materials

4. Clarifiers remove microorganisms and remaining solids

5. Filtering makes water clear 
6. Disinfection, usually with chlorine, kills the remaining microorganisms

Reuse facilities are constantly monitored to ensure that only high-quality reclaimed water is distributed. This water is clear and essentially pathogen-free.

\section{Reclaimed Water Supply Distribution Plant}

After the recycling of water in waste water treatment plant it comes for distribution plant. Reclaimed water is often distributed with a dual piping network that keeps reclaimed water pipes completely separate from potable water pipes.

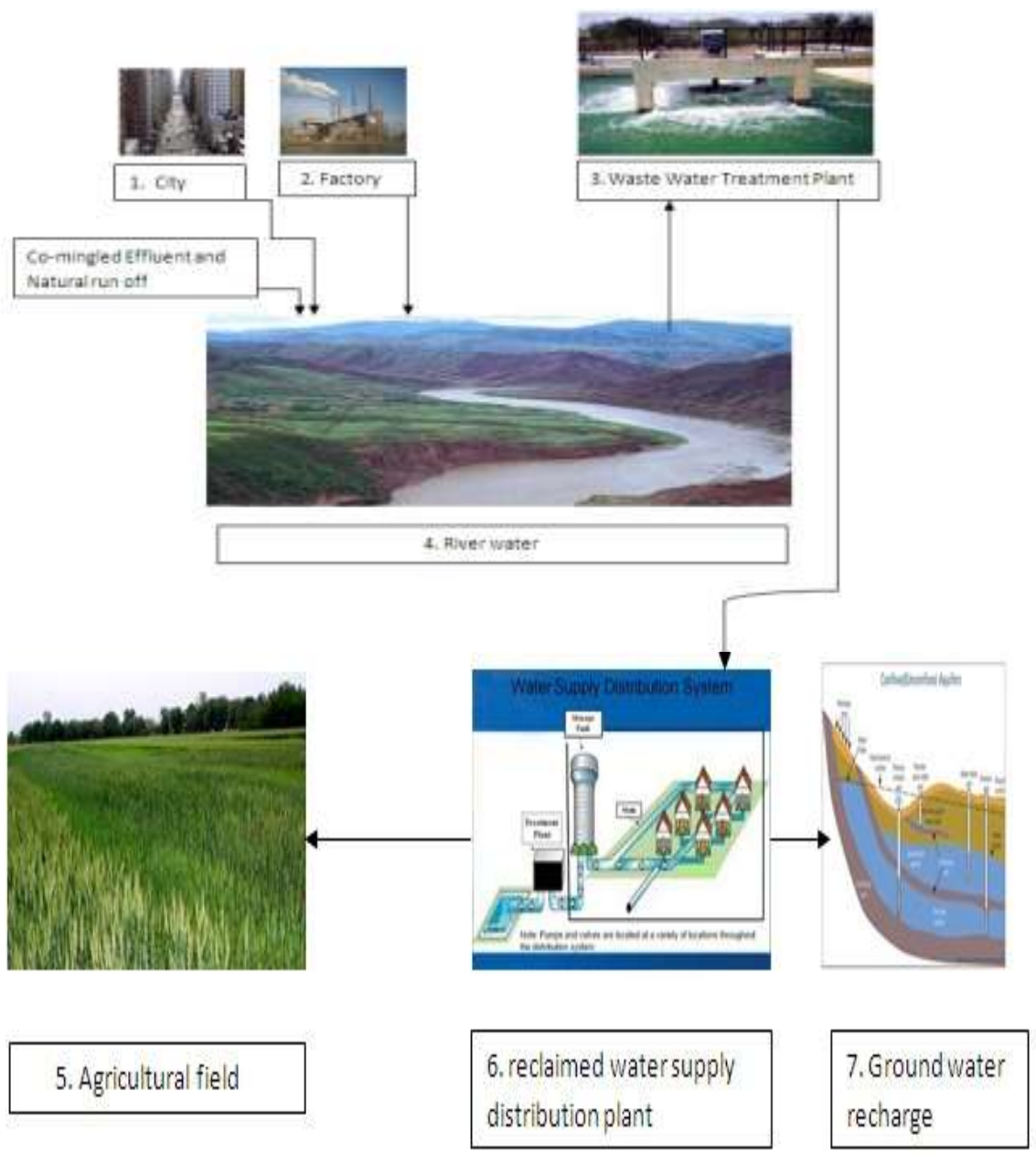

Figure 1:- Waste Water Treatment Plant (or) Reclaimed Water Distribution Plant

\section{Maximum Water Recovery}

To determine maximum water recovery there are various techniques that have been developed by researchers; for maximum water reuse/reclamation/recovery strategies such as Water Pinch Analysis. The techniques help users to target the minimum freshwater consumption and minimum wastage of water. It provides a benchmark to be used by users in improving their water systems.

Tertiary treatment consists of further removal of suspended and dissolved solids, including:

- $\quad$ nutrient (nitrogen and/or phosphorus) removal by biological or chemical methods.

- removal of organics and metals by carbon adsorption or chemical precipitation.

- further removal of suspended and dissolved solids by filtration, coagulation, ion exchange, reverse osmosis, and other techniques.

- removal of organic chemicals by oxidation with hydrogen peroxide or ozone.

Reclaimed water is disinfected by advanced treatments before releasing. It often requires greater treatment than effluent that is discharged to local streams or rivers because users will typically have more direct contact with undiluted reclaimed water than undiluted effluent. 


\section{Reclaimed Water Quality Considerations}

Water quality must be considered when using reclaimed water for irrigation. The following properties are critical to plant, soil, health and environmental quality. Salinity, or salt concentration, is probably the most important consideration in determining whether water is suitable for reuse. Water salinity is the sum of all elemental ions (e.g., sodium, calcium, chloride, boron, sulfate, nitrate) and is usually measured by determining the Electrical Conductivity (EC, units $=\mathrm{ds} / \mathrm{m}$ ) or Total Dissolved Solids (TDS, units $=\mathrm{mg} / \mathrm{L}$ ) concentration of the water. Water with a TDS concentration of $640 \mathrm{mg} / \mathrm{L}$ will typically have an EC of approximately $1 \mathrm{ds} / \mathrm{m}$.

- Salts in reclaimed water come from:

- Elemental ions naturally found in water.

- Ions retained in dissolved form after separation of solids during water treatment.

- Any salts added during the water treatment process

Most reclaimed water from urban areas is slightly saline (TDS $\leq 1280 \mathrm{mg} / \mathrm{L}$ or EC $\leq 2 \mathrm{ds} / \mathrm{m}$ ). High salt concentrations reduce water uptake in plants by lowering the osmotic potential of the soil. For instance, residential use of water adds approx. 200-400 mg/L dissolved salts (Lazarova et al., 2004a). Plants differ in their sensitivity to salt levels. The salinity of the particular reclaimed water source should be measured so that, appropriate crops and/or application rates can be selected. Most turf grasses can tolerate water with 200-800 $\mathrm{mg} / \mathrm{L}$ soluble salts, but salt levels above $2,000 \mathrm{mg} / \mathrm{L}$ may be toxic (Haryanvi, 2004). For further information on managing turfgrasses when irrigating with saline water, see Carrow and Duncan. Many other crop and landscape plants are more sensitive to high soluble-salt levels than turf grasses, and should be managed accordingly like concentration of sodium, chloride, and boron.

\section{Nutrient levels}

Reclaimed water typically contains more nitrogen $(\mathrm{N})$ and phosphorus $(\mathrm{P})$ than drinking water. The amounts of $\mathrm{N}$ and $\mathrm{P}$ provided by the reclaimed water can be calculated as the product of the estimated irrigation volume and the $\mathrm{N}$ and $\mathrm{P}$ concentration in the water. Water Reclamation and Reuse Regulation requires that a nutrient management plan be written for bulk use of reclaimed water not treated to achieve biological nutrient removal (BNR). Water that has been subjected to BNR treatment processes contains low concentrations of $\mathrm{N}$ and P such that the reclaimed water can be applied at rates sufficient to supply a crop's water needs without risk of surface or ground water contamination.

\section{Health Risks}

On investigating the risks and effects of irrigation with reclaimed water on food crops, including raweaten vegetables, it was found that no viruses were reported on samples of crops from experimental plots irrigated with reclaimed water. Additionally, the levels of naturally occurring bacteria were not significantly different between well-water-irrigated crops and reclaimed-water-irrigated crops. There were also no adverse health effects to farmers detected from exposure of reclaimed water constituents. In fact, the quality, yield, and longevity of all the crops irrigated with reclaimed water were equal to or better than those of the crops grown with well water

IX. Drinking Water Indicators

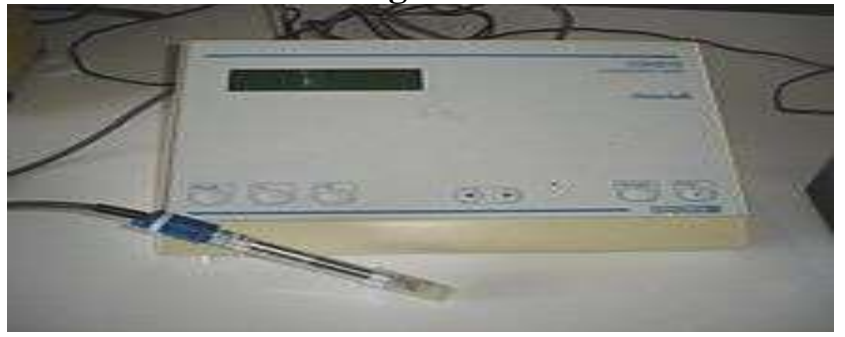

Figure 2: Electronic Drinking Water Indicator

The following is a list of indicators often measured by situational category:

- Alkalinity

- Color of water

- $\mathrm{pH}$

- Taste and odor (geosmin, 2-Methylisoborneol (MIB), etc.)

- Dissolved metals and salts (sodium, chloride, potassium, calcium, manganese, magnesium)

- Microorganisms such as fecal coliform bacteria (Escherichia coli), Cryptosporidium, and Giardia lamblia

- Dissolved metals and metalloids (lead, mercury, arsenic, etc.)

- Dissolved organics: colored dissolved organic matter (CDOM), dissolved organic carbon (DOC) 
- Radon

- Heavy metals

- Pharmaceuticals

- Hormone analogs

\section{X. $\quad$ Electronic Water Level Indicator}

Water level indicator detects what is the level of water in the field. Mostly these electronic water level indicators are used in boilers,

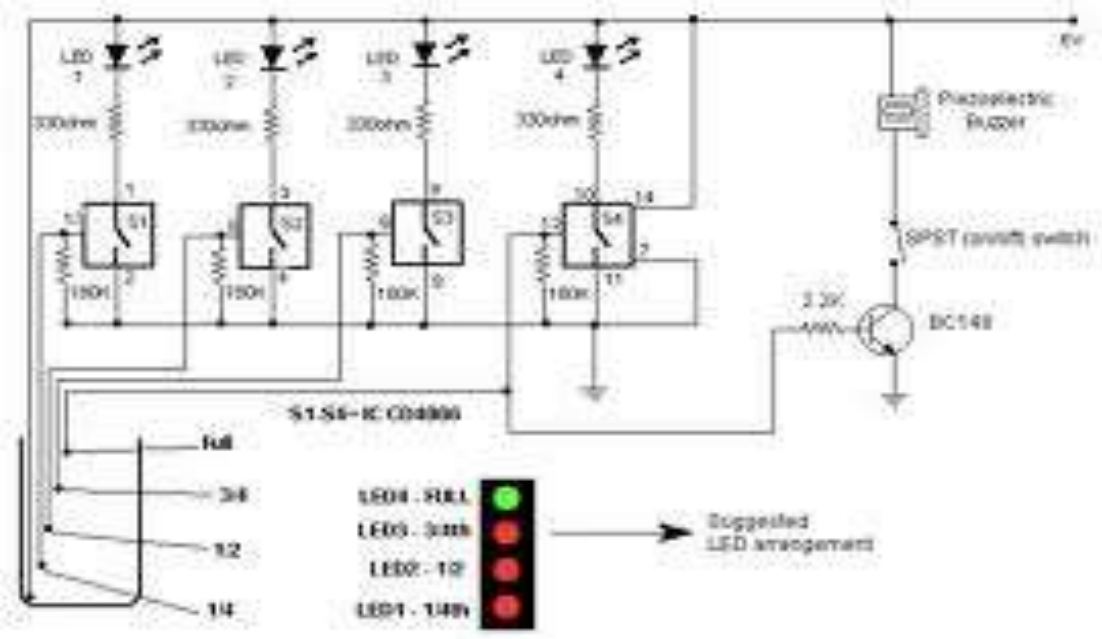

Figure 3: Electronic Water Level Indicator

\section{Software for treating wastewater}

Computer software, or software, is a collection of computer programs and related data that provides the instructions for a computer what to do and how to do it. Programs are an ordered sequence of instructions for changing the state of the computer in a particular sequence. Program software performs the function of the program it implements, either by directly providing instructions to the computer hardware or by serving as input to another piece of software. At the lowest level, executable code consists of machine language instructions specific to an individual processor. A machine language consists of groups of binary values signifying processor instructions that change the state of the computer from its preceding state. It is usually written in high-level programming languages that are easier and more efficient for humans to use (closer to natural language) than machine language. High-level languages are compiled into machine language object code.

1. Adopting software technology in waste water treatment plant:-By adopting software technology in reclaimed water distributed plant, it is easier to find out:-

a. What is the nature water

b. How much waste water is entering into the treatment plant

c. What are the waste content existing in the water

d. What are the useful minerals that existing are not to removed in recycling

2. Adopting latest computer techniques to this problem makes agricultural farmer process easier:-In reclaimed water distributed plant, waste water is recycled according to feasible quality usage of agriculture fields. With the help of reclaimed distributed treatment plant, we can measure how much is the intake should be (water). How much water level should be maintained throughout the year these things can be done by reclaimed distributed treatment plant by using latest computer technology?

By adopting software technology we can get accurate result. With the help of software programming we can connect both water level indicator and water quality detector. By connecting these two instruments with computer software, one time farmer can fix readings based on the.

1. What is the length and breadth of the field?

2. How much quality of water it requires?

3. What are the water levels to be maintained in the field?

This helps the farmers in better management of the waste water and can help in solving their problem with the help of latest computer technology. 


\section{Conclusion}

The main motto is to make agricultural farmer more convenient while he is in cultivation, and making him tension free from use of waste water. By using the software technology up to some extent farmers can reduce their problems.

\section{References}

[1] Drechsel P., Graefe S., Sonou M. and Cofie, O. (2006) Informal irrigation in urban West Africa: an overview. International Water Management Institute (IWMI), Colombo. Research Report 102. www.iwmi.org

[2] Keraita B., Drechsel P. and Amoah, P. (2003) Influence of urban wastewater on stream water quality and agriculture in and around Kumasi, Ghana. Environment and Urbanization 15(2): 171-178.

[3] Asano, T., Burton, F.L., Leverenz, H.L., Tsuchihashi, R. and Tchobanoglous, G. (2007) Water reuse: issues, technologies, and applications., New York, USA: McGraw-Hill

[4] Obuobie E., Keraita B., Danso G., Amoah P., Cofie O.O., Raschid-Sally, L. and Drechsel, P. (2006) Irrigated urban vegetable production in Ghana: characteristics, benefits and risks. IWMI: IWMI-RUAF-IDRC-CPWF, Accra, Ghana. http://www.cityfarmer.org/GhanaIrrigateVegis.html

[5] Levine, Audrey D.; Takashi Asano (1 June 2004). "Peer Reviewed: Recovering Sustainable Water from Wastewater". Environmental Science \& Technology 45: 203A. doi:10.1021/es040504n. Retrieved 20 March 2012.http://www.epa.gov/region09/water/recycling/

[6] $\square \wedge$ _Space.com. (2009, May 20). Astronauts Drink Recycled Urine, and Celebrate. Retrieved November 29, 2009 from http://www.space.com/missionlaunches/090520-space-urine.html

[7] $\square \wedge$ W WaterSaver Technologies Aqus Uses Sink Greywater for Toilet. Treehugger.com. October 7, 2006. Retrieved May 22, 2007.http://www.treehugger.com/files/2006/10/watersaver_tech.php 